McGill Law Journal

Revue de droit de McGill

\title{
Siobhán Wills, Protecting Civilians: The Obligations of Peacekeepers (Oxford: Oxford University Press, 2009), pp xxi, 296. ISBN 978-0-19-953387-9
}

\section{Hilmi M. Zawati}

Volume 57, numéro 2, december 2011

URI : https://id.erudit.org/iderudit/1007821ar

DOI : https://doi.org/10.7202/1007821ar

Aller au sommaire du numéro

Éditeur(s)

McGill Law Journal / Revue de droit de McGill

ISSN

0024-9041 (imprimé)

1920-6356 (numérique)

Découvrir la revue

Citer ce compte rendu

Zawati, H. M. (2011). Compte rendu de [Siobhán Wills, Protecting Civilians: The Obligations of Peacekeepers (Oxford: Oxford University Press, 2009), pp xxi, 296. ISBN 978-0-19-953387-9]. McGill Law Journal / Revue de droit de McGill, 57(2), 383-392. https://doi.org/10.7202/1007821ar d'utilisation que vous pouvez consulter en ligne. 
McGill Law Journal Revue de droit de McGill

BOOK REVIEW-

Siobhán Wills, Protecting Civilians: The Obligations of Peacekeepers (Oxford: Oxford University Press, 2009), pp xxi, 296. ISBN 9780-19-953387-9.

\section{Hilmi M. Zawati*}

The last two decades have witnessed the highest ever involvement of United Nations' blue helmets in peacekeeping missions throughout the world. These international missions, as Siobhán Wills observes, consist of different types of peace and enforcement operations, including conflict prevention, peacemaking, peace enforcement, peace building, and humanitarian operations. ${ }^{1}$ The engagement of UN troops in civilian protection operations in the world's war-torn areas has resulted in several complications concerning their mandates to protect civilians from harm on the one hand, and their entanglement in human rights violations on the other. ${ }^{2}$

* Hilmi M. Zawati, DCL (McGill), MA in international comparative law (McGill), PhD (CPU), MA (Punjab), Post-Graduate Diploma in law (Khartoum), LLB (BAU), is currently president of the International Legal Advocacy Forum (ILAF), and an international criminal law jurist and human rights advocate. Zawati's most recent work is his book Symbolic Judgments or Judging Symbols: Fair Labelling and the Dilemma of Prosecuting Gender-Based Crimes under the Statutes of the International Criminal Tribunals, Forthcoming, 2012. I would like to thank Ibtisam M Mahmoud, librarian, McGill University Health Centre, Ma'n H Zawati, DCL Candidate, McGill Law School, for research material, and Steve Millier for reading the early draft of this review.

(c) Hilmi M. Zawati 2011

Citation: (2011) 57:2 McGill LJ 383 Référence : (2011) 57 : 2 RD McGill 383

1 Siobhán Wills, Protecting Civilians: The Obligations of Peacekeepers (Oxford: Oxford University Press, 2009) at 86.

2 Francis Elliott \& Ruth Elkins, "UN Shame over Sex Scandal" The Independent (7 January 2007), online: The Independent <http://www.independent.co.uk>; Lise Morjé Howard, UN Peacekeeping in Civil Wars (Cambridge: Cambridge University Press, 2008) at 336; Maggie Farley, "Abuse by U.N. Troops Entrenched" Los Angeles Times (19 October 2005), online: Los Angeles Times <http://www.latimes.com>; Mike Pflanz, "Six-YearOlds Sexually Abused by UN Peacekeepers" The Telegraph (26 May 2008), online: The Telegraph Group <http://www.telegraph.co.uk>; Max Du Plessis \& Stephen Pete, "Who Guards the Guards? The ICC and Serious Crimes Committed by United Nations Peacekeepers in Africa" (2004) 13:4 African Security Review 5; Mark Steyn, "UN Forces: Just a Bunch of Thugs?" The Telegraph (15 February 2005), online: The Telegraph Group <http://www.telegraph.co.uk>; "Peacekeeping and Sex Abuse: Who Will Watch the Watchmen?" The Economist (29 May 2008), online: The Economist $<$ http://www.economist.com>; Sandra Whitworth, Men, Militarism, and UN Peacekeeping: A Gendered Analysis (Boulder, Colo: Lynne Rienner, 2004) at 185; "The Worse U.N. 
In light of these developments, a fresh look into the norms of international humanitarian law (IHL) and international human rights law is necessary to remind troops of their obligation to protect civilians from human rights abuses and, at the same time, hold members of these missions accountable for alleged crimes and violations. Thus, the purpose of Protecting Civilians, The Obligations of Peacekeepers is to examine in depth international humanitarian and human rights law instruments and demonstrate how these laws impose obligations on UN peacekeepers and other multinational forces to protect civilians in war-torn areas of the world, including intervention to prevent or stop human rights violations and restore law in UN-occupied areas.

Focusing on the challenges faced by peacekeeping missions in implementing their mandates, the author devotes the first chapter of her book to providing a historical review of peacekeepers' successes and failures in protecting civilians. She explores how these troops, on different occasions, did less than nothing when civilians were at risk of becoming victims of serious violations, such as the collective blood baths and mass rape campaigns in Bosnia-Herzegovina, Rwanda, and other ravaged areas of the world. In spite of the fact that UN troops were authorized to take "all appropriate measures" 3 to protect civilians and to use force in case of "selfdefence", ${ }^{4}$ these troops repeatedly failed either to implement these mandates or to protect themselves, as when they were attacked in Kigali and

Scandal", Editorial, The New York Times (24 October 2005), online: The New York Times <http://www.nytimes.com>.

3 Wills, supra note 1 at 281; Resolution 1820 S Res 1820, UNSCOR, 2008, UN Doc S/RES/1820, (19 June 2008).

4 The UN worked side by side with the European Community (EC) for the settlement of the Yugoslav conflict. On 3 January 1992, a ceasefire was in place, following an agreement signed in Geneva between the governments of Croatia and Serbia to end hostilities between their armies. By 17 January 1992, UN military observers were deployed throughout Croatia. Although this ceasefire was broken several times, including the downing of the EC ceasefire monitors' helicopter, the UN secretary general confirmed that the UN peacekeeping units would use minimal force and only in self-defence. The UN Protection Force's limited mandate encouraged Serbs to dictate their conditions and inspired a culture of impunity. See United Nations Peacekeeping Operations: Principles and Guidelines (New York: United Nations Department of Peacekeeping Operations, 2008) at 31; Frances Pilch \& Joseph Derdzinski, "The UN Response to the Balkan Wars," in Jeffrey S Morton et al, eds, Reflections on the Balkan Wars: Ten Years After the Break Up of Yugoslavia (New York: Palgrave Macmillan, 2004) 93 at 95; Hans Stark, "Histoire immédiate de la guerre Yougoslave" dans Cécile Monnot \& Jean Cot, Dernière guerre Balkanique? Ex-Yougoslavie: témoignages, analyses, perspectives (Paris: L'Harmattan, 1996) at 19; Report of the Secretary-General Pursuant to Security Council Resolution 749 (1992), UNSCOR, 1992, UN Doc S/23836. 
lost ten of their members. ${ }^{5}$ Moreover, it was reported that the UN Assistance Mission for Rwanda and the UN Protection Force abandoned thousands of civilians in the Kigali École Technique Officielle and in Srebrenica to be slaughtered by Hutu and Serb forces, respectively. ${ }^{6}$

Chapter 2 of this analysis examines the extent to which international humanitarian law obliges peacekeeping forces to protect civilians from human rights abuses. Relying on her extensive research, Wills explains that the ambiguity of obligations imposed on UN peacekeeping missions to protect civilians during armed conflict under IHL — particularly common article 1 to the 1949 Geneva Conventions ${ }^{7}$ - has resulted in many incompatibilities in peacekeepers' mandates. This vagueness has encouraged the UN to treat the above laws as mere political perspective rather than as binding law. Finally, the author concludes by claiming that treating the norms of IHL - as they relate to UN troops-as moral standards rather than laws compelling obedience has undermined many peacekeeping missions and caused the failure of these operations in different regions of the world. ${ }^{8}$

By the same token, Wills tries, in chapter 3, to ascertain the applicability of international human rights law to UN peacekeeping missions and to determine whether these laws impose obligations on UN troops and

5 Hilmi M Zawati, The Triumph of Ethnic Hatred and the Failure of International Political Will: Gendered Violence and Genocide in the Former Yugoslavia and Rwanda (Lewiston, NY: The Edwin Mellen Press, 2010) at 210; Romeo Dallaire \& Bruce Poulin, "Rwanda: From Peace Agreement to Genocide" (1995) 24:3 Canadian Defence Quarterly 7 at 9 .

6 Astri Suhrke, "Dilemmas of Protection: The Log of the Kigali Battalion," in Howard Adelman \& Astri Suhrke, eds, The Path of a Genocide: The Rwanda Crisis from Uganda to Zaire (New Brunswick, NJ: Transaction, 1999) 253; Raymond W Copson, Africa's Wars and Prospects for Peace (Armonk, NY: M E Sharpe, 1994); Susan E Cook, "The Politics of Preservation in Rwanda" in Susan E Cook, ed, Genocide in Cambodia and Rwanda: New Perspectives (New Brunswick, NJ: Transaction, 2006) 281; John F Burns, "UN disarms Muslim defenders of Srebrenica", The [Montreal] Gazette (22 April 1993) A18; Zawati, supra note 5 at 235.

7 Geneva Convention for the Amelioration of the Condition of the Wounded and Sick in Armed Forces in the Field, 12 August 1949, 75 UNTS 31, Can TS 1965 No 20 [Geneva Convention I]; Geneva Convention for the Amelioration of the Condition of Wounded, Sick and Shipwrecked Members of Armed Forces at Sea, 12 August 1949, 75 UNTS 85, Can TS 1965 No 20 [Geneva Convention II]; Geneva Convention Relative to the Treatment of Prisoners of War, 12 August 1949, 75 UNTS 135, Can TS 1965 No 20 [Geneva Convention III]; Geneva Convention Relative to the Protection of Civilian Persons in Time of War, 12 August 1949, 75 UNTS 287, Can TS 1965 No 20 [Geneva Convention $I V]$.

8 Wills, supra note 1 at 45; Estelle Inès Nkounkou-Ngongo, Protection of Children's Rights in Peacekeeping Missions: Analysis of Sexual Exploitation and Sexual Abuse (LLM Dissertation, University of Makerere Faculty of Law, 2007) [unpublished] at 7. 
multinational forces to protect civilians during armed conflict. The author relies on different perspectives - particularly that of IHL - to examine the applicability of human rights law to armed conflicts, and then reviews historical developments in IHL and international human rights law since the 1960s. Moreover, in examining different cases, she explores the relationship between international human rights law and other regimes, namely occupation law and IHL. Wills concludes by asserting that, despite the fact that many questions about peacekeepers' responsibilities in protecting civilian populations remain undetermined, human rights law is still applicable during armed conflict. This notion has been supported by the jurisprudence of the International Court of Justice, regional human rights courts, UN human rights bodies, and the reports of the International Committee of the Red Cross. In this respect, the Human Rights Committee has provided that the UN is bound by international human rights law in territories under its administration and that, accordingly, UN peacekeepers are not immune from its investigation. ${ }^{9}$ However, this proclamation does not go so far as to say that UN troops may be held accountable for violations of their human rights obligations in international or national courts, except when they are deployed without a UN Security Council resolution.

Wills insists that, even though the UN is not a party to IHL treaties and consequently cannot be expected to carry out all obligations included in these treaties, it is widely accepted that UN troops must respect the "principles and spirit" of the laws of war. ${ }^{10}$ However, this "respect" does not impose any obligation on UN peacekeepers to prevent violations of IHL or require that they be held responsible for their felonies in territories under their control. ${ }^{11}$ On that basis, ruling on violations of IHL committed by UN troops in Somalia, both the Canadian court martials and the Belgian military court concluded that IHL did not apply to UN peacekeeping forces in Somalia, ${ }^{12}$ decisions that enraged human rights groups and activists.

9 Wills, supra note 1 at 168 .

10 Wills, supra note 1 at 248.

11 Marco Odello, "Tackling Criminal Acts in Peacekeeping Operations: The Accountability of Peacekeepers" (2010) 15:2 J Confl \& Sec L 347 at 373; Peter Rowe, "United Nations Peacekeepers and Human Rights Violations: The Role of Military Discipline", online: (2010) 51 Harv Int'l LJ Online 69 at $78<$ http://www.harvardilj.org>; Wills, supra note 1 at $188-89$.

12 Wills, supra note 1 at $91,262$. 
Nonetheless, the author examines in chapter 4 of her analysis the question of the applicability of occupation laws ${ }^{13}$ to the UN forces involved in humanitarian intervention or peacekeeping operations, notwithstanding that the UN is not a state party to these conventions and that its troops are not considered to be belligerent occupation forces. After a considerable analysis of different cases-particularly the status of the United Nations Operation in Somalia, the Kosovo Force, the United Nations Interim Administration Mission in Kosovo, and the multinational forces in Iraq-Wills concludes that the question of the applicability of the laws of occupation to UN operations is an issue that is open to discussion and controversy. ${ }^{14}$ While some commentators argue that Security Council Resolution 1483 made it clear that the laws of occupation may be applicable to operations mandated by the UN, others were reluctant to consider the UN-run operations as comparable to military occupation..$^{15}$

In the light of the outcomes of previous chapters, Wills tries in chapter 5 of this work to determine the scope of the UN peacekeepers' and other multinational forces' obligations to protect civilians from serious violations of human rights, including those committed by third parties against local populations.

The author develops the argument that UN peacekeepers and forces alike have both moral and legal obligations to stop violence against civilians, whether as troops mandated by the UN or as subjects of contributing states bound by the norms of international humanitarian law conventions. In this respect, she refers to the concept of the collective "responsibility to protect", ${ }^{16}$ and to common article 1 to the 1949 Geneva

13 These occupation laws are incorporated in regulations annexed to the Convention Respecting the Laws and Customs of War on Land, 18 October 1907, 36 US Stat 2277, 1 TI Agree 631 (1907 Hague Convention); the Geneva Convention IV, supra note 7; and the Protocol Additional to the Geneva Conventions of 12 August 1949, and Relating to the Protection of Victims of International Armed Conflicts, 8 June 1977, 1125 UNTS 3, Can TS 1991 No. 2 (Protocol I).

14 Wills, supra note 1 at 242.

15 Ibid at 234-35.

16 Ibid at 252. The concept of the collective "responsibility to protect" was developed by the International Commission on Intervention and State Sovereignty in 2001. For more on this concept, see Alex J Bellamy \& Paul D Williams, "On the Limits of Moral Hazard: The 'Responsibility to Protect', Armed Conflict and Mass Atrocities”, online: (2011) European Journal of International Relations $1<\mathrm{http}$ ://ejt.sagepub.com>; Anne Peters, “The Security Council's Responsibility to Protect" (2011) 8:1 International Organizations Law Review 1; Gareth Evans \& Mohamed Sahnoun, "The Responsibility to Protect" (2002) 81:6 Foreign Affairs 99; Hitoshi Nasu, "Operationalizing the Responsibility to Protect in the Context of Civilian Protection by UN Peacekeepers" (2011) 18:4 International Peacekeeping 364 ; Michael W Doyle, "International Ethics and the Responsibility to Protect" (2011) 13:1 International Studies Review 72; Sabine Hassler, "Peace- 
Conventions, which provides for the duty to "respect and ensure respect for" international humanitarian law. ${ }^{17}$ Although these provisions are directed at states or organizations, they nevertheless impose indirect responsibility on individual peacekeepers to protect civilians from violations of their fundamental human rights. Nonetheless, in connection with the above discussion, the author would argue that the duty to protect civilians from violations of human rights can also be derived from the jus cogens and erga omnes legal concepts, which prohibit such violations on the basis of the common interest of the international community. ${ }^{18}$

In fact, the principle of international collective responsibility to protect civilians emerged and was emphasized in the mandates of peacekeeping missions in the aftermath of the Rwandan genocide and Srebrenica mass killings, in 1994 and 1995 respectively. Since then, this principle has become a clear norm within the obligations of peacekeepers and multinational forces whether deployed according to a UN Security Council resolution or authorized by regional organizations. In spite of these instructions, some peacekeeping missions have utterly failed to protect civilians, while others have been actively involved in the violation of civilians' human rights, including sexual exploitation and abuse..$^{19}$

keeping and the Responsibility to Protect" (2010) 14:1/2 Journal of International Peacekeeping 134; S Neil MacFarlane, Carolin J Thielking \& Thomas G Weiss, "The Responsibility to Protect: Is Anyone Interested in Humanitarian Intervention?” (2004) 25:5 Third World Quarterly 977.

17 Common art 1 to Geneva Conventions I-IV, supra note 7.

18 Dean Adams, "The Prohibition of Widespread Rape as a Jus Cogens" (2005) 6:2 San Diego Int'l LJ 357; David S Mitchell, "The Prohibition of Rape in International Humanitarian Law as a Norm of Jus Cogens: Clarifying the Doctrine" (2005) 15:2 Duke J Comp \& Int'l L 219 at 225.

19 Jehan Khaleeli \& Sarah Martin, "Addressing the Sexual Misconduct of Peacekeepers", Refugees International (23 September 2004); Colum Lynch, "U.N. Faces More Accusations of Sexual Misconduct", The Washington Post (13 March 2005) A22; Children and Armed Conflict: Report of the Secretary-General, UNGAOR/UNSCOR, 59th Sess, UN Doc A/59/695, (2005); Special Measures for Protection from Sexual Exploitation and Sexual Abuse: Report of the Secretary-General, UNGAOR, 60th Sess, UN Doc A/60/861, (2006) at para 17; Scott A Levin, "Sexual Exploitation of Refugee Children by U.N. Peacekeepers" (2003) 19:3 NYL Sch J Hum Rts 833; Secretary-General's Bulletin: Special Measures for Protection from Sexual Exploitation and Sexual Abuse, Secretariat, 2003, UN Doc ST/SGB/2003/13; United Nations Interregional Crime and Justice Research Institute, Trafficking in Human Beings and Peace-Support Operations: PreDeployment/In-Service Training Programme for International Law-Enforcement Personnel, $2 \mathrm{~d}$ ed (Turin: United Nations Interregional Crime and Justice Research Institute, 2006) at 67; UNSC, News Release, UN Doc SC/8400, "Security Council Condemns 'in the Strongest Terms' All Acts of Sexual Abuse, Exploitation by UN Peacekeeping Personnel" (31 May 2005), online: UN Meetings Coverage \& Press Releases $<$ http://www.un.org/en/unpress>; Resolution 1400, S Res 1400, UNSCOR, 2002, UN Doc S/RES/1400 at art 14 ("[e]xpresses its serious concern at allegations that some United 
As indicated earlier, peacekeeping and multinational operations have become a focus of legal studies. This is not because they have served as one of the UN's tools to preserve peace and security around the world since the establishment of the UN Truce Supervision Organization in 1948 , but due to their repeated failure to prevent or stop mass violations against civilians, relying on the notion that intervening to stop human rights violations could be understood as supporting one side of the conflict against the other or losing impartiality. ${ }^{20}$ Moreover, these missions were

Nations personnel may have been involved in sexual abuse of women and children in camps for refugees and internally displaced people in the region" [emphasis in original]); Resolution 1436, S Res 1436, UNSCOR, 2002, UN Doc S/RES/1436 at art 15 ("[w]elcomes steps taken by UNAMSIL to prevent sexual abuse and exploitation of women" in Sierra Leone peacekeeping mission [emphasis in original]); Resolution 1460, S Res 1460, UNSCOR, 2003, UN Doc S/RES/1460 at art 10 ("[n]otes with concern all the cases of sexual exploitation and abuse of women and children, especially girls, in humanitarian crisis, including those cases involving humanitarian workers and peacekeepers" [emphasis in original]); Resolution 1565, S Res 1565, UNSCOR, 2004, UN Doc S/RES/1565 at arts 1, 25 (renews the United Nations Organization Mission in the Democratic Republic of the Congo's (MONUC) mandate and requests the secretary general to investigate allegations of sexual exploitation and misconduct); Resolution 1590, S Res 1590, UNSCOR, 2005, UN Doc S/RES/1590 at 2 ("[s]trongly condemning all violations of human rights and international humanitarian law in the Darfur region, in particular the continuation of violence against civilians and sexual violence against women and girls" [emphasis in original]); Resolution 1794, S Res 1794, UNSCOR, 2007, UN Doc S/RES/1794 at art 18 ("[r]equests MONUC, in view of the scale and severity of sexual violence committed especially by armed elements in the Democratic Republic of Congo, to undertake a thorough review of its efforts to prevent and respond to sexual violence, and to pursue a comprehensive mission-wide strategy, in close cooperation with the United Nations Country Team and other partners" [emphasis in original]); "Update Report No 3: Sexual Exploitation and Abuse by UN Peacekeeping Personnel" Security Council Report (20 February 2006), online: Security Council Report <http:// www.securitycouncilreport.org>.

20 Shyla Vohra, "Impartiality in United Nations Peace-Keeping” (1996) 9:1 Leiden J Int'l L 63 at $76 \mathrm{ff}$. On the contrary, it has been reported that two French NATO officers passed sensitive information about NATO plans to arrest Karadži and bomb military targets in Yugoslavia. Major Herve Gourmelon, an Implementation Force French military officer whose job was to maintain contacts with Bosnian Serbs, had met repeatedly with Karadži, thereby frustrating plans to arrest the latter. By the same token, Major Pierre Bunel, who was working at the NATO headquarters in Brussels as chief of staff to France's top military representative, confessed in his meeting with French investigators that he had passed sensitive information to Belgrade about the details of the NATO plans for punitive air strikes against Serb military targets. See Anne Swardson, "French Officer Accused of Spying for Yugoslavia", The Washington Post (3 November 1998) A12; Ben Macintyre, "Serbs 'were given Nato targets", The Times (3 November 1998) 1; Charles Bremner, "Spy case damages French bid for key Kosovo role", The Times (4 November 1998) 16; "French Major Held in Spying at NATO Panel", The New York Times (3 November 1998) A8; John Lichfield, "France accused over genocide in Rwanda", The Independent (9 April 1998), online: The Independent <http://www. independent.co.uk>; Julian Nundy \& Chris Stephen, "French hold officer who spied for Yugoslavia", The Scotsman (3 November 1998), online: <http://www.scotsman.com>; 
criticized for alleged crimes and violations of human rights committed by their members against protected people, specifically sexual exploitation, smuggling through borders, trafficking in women and girls, ${ }^{21}$ and sexual scandals, including "sex for food". 22

Where there was no peace to keep, and bound by inappropriate mandates, UN troops overwhelmingly failed to prevent the tragic massacre of approximately eight thousand Bosnian Muslims by Serb forces and paramilitaries in Srebrenica, a UN safe haven, in the summer of $1995 .{ }^{23} \mathrm{Sim}$ ultaneously, in spite of several alarming reports, the UN peacekeeping mission in Rwanda, led by the Canadian General Roméo Dallaire, could not stop the mass killings of eight hundred thousand Tutsi and Hutu civilians, in 1994, due to the reluctance of the United Nations Department of Peacekeeping Operations (UNDPKO) to provide adequate troops to properly carry out the mission's mandate. ${ }^{24}$ This failure caused General

Robert Graham, "French officer accused of leaking secrets to Serbs", Financial Times (4 November 1998) 2; Zawati, supra note 5 at 222.

21 Melanie O'Brien, National and International Criminal Jurisdiction over United Nations Peacekeeping Personnel for Gender-Based Crimes against Women (PhD Thesis, University of Nottingham, 2010) [unpublished] at 271-72; Valorie K Vojdik, "Sexual Abuse and Exploitation of Women and Girls by U.N. Peacekeeping Troops" (2007) 15:1 Mich St J Int'l L 157 at 158; Wills, supra note 1 at 225-26, 272-82.

22 Claire Morris, "Peacekeeping and the Sexual Exploitation of Women and Girls in PostConflict Societies: A Serious Enigma to Establishing the Rule of Law" (2010) 14:1/2 Journal of International Peacekeeping 184 at 189; Emily Wax, "Congo's Desperate 'One-Dollar U.N. Girls”, The Washington Post (21 March 2005) A1, A14; Jonathan Clayton \& James Bone, "Sex scandal in Congo threatens to engulf UN's peacekeepers", The Times (23 December 2004) 25; Sarah Martin, Must Boys be Boys?: Ending Sexual Exploitation \& Abuse in UN Peacekeeping Missions (Washington, DC Refugees International, 2005), online: Refugees International <http://www.refugeesinternational. org> at 4; Stephanie Nolen, “Not Women Anymore ...': The Congo's Rape Survivors Face Pain, Shame and AIDS", Ms. 15:1 (Spring 2005) 56 at 58; UNSC, Press Release, "Sexual Exploitation Allegations Related to UN Mission in Democratic Republic of Congo" (22 November 2004), online: <http://www.un.org>.

23 See Douglass W Cassel, "Srebrenica: The faces of evil," Chicago Daily Law Bulletin (9 August 2001) 6; John F Burns, "Serbs demand Canadians be pulled out of Srebrenica: 146 soldiers stand between 30,000 civilians and heavily armed besieging force", The [Montreal] Gazette (27 April 1993) A12.

24 Howard Adelman \& Astri Suhrke, Early Warning and Conflict Management: Genocide in Rwanda (Bergen: Michelsen Institute, 1996) at 68, 71; Human Rights Watch, News Release, "Rwandan Genocide Could Have Been Stopped: Comprehensive Study Points Finger at U.S., U.N., France, Belgium" (31 March 1999), online: Human Rights Watch $<$ http://www.hrw.org>; Lieutenant-General Roméo Dallaire, Shake Hands with the Devil: The Failure of Humanity in Rwanda (Toronto: Vintage Canada, 2004) at 514. 
Dallaire to ask his famous question: "Are we all human, or are some more human than others?"25

These issues raise various questions relating to peacekeepers' collective obligations to protect civilians under international humanitarian and human rights law, the possibility of holding them accountable for their crimes, and whether the UN peacekeeping missions are bound by the norms of local or international laws of armed conflict. Considering the dramatic changes and complexity in recent peace support operations, the main concern of legal inquiries ought to shift from merely focusing on these missions' obligations under international law to protect civilians and bring peace and security to areas devastated by war to laying down the foundation of a legal framework to eradicate peacekeepers' violations and bring perpetrators to justice-not only repatriating them to their contributing states.

Many of the above concerns are meticulously addressed by Siobhán Wills in this timely, critical, and well articulated work-originally submitted to All Souls College, Oxford University, as a doctoral thesis-by carefully analyzing the many inadequacies in the mandate of peacekeeping missions, caused by the lack of international political will and manifested in the tragic failure to stop mass killings and other atrocities in BosniaHerzegovina, Rwanda, Kosovo, Congo, and other regions of the world racked by war. 26

In sum, this work contributes to the development of a legal literature that will undoubtedly assist the UNDPKO in overcoming previous short-

25 The international community had failed utterly in the post-Cold War era to observe its duties in preserving international peace and security, placing the principles of international humanitarian and human rights law-embedded in international and regional conventions and treaties-in question. Like General Dallaire, we in the West certainly have no difficulty to believe that our lives are worth more than the lives of other people in this world: we should remember that the Dutch and French peacekeepers allowed the fall of Srebrenica and the massacre of more than eight thousand Bosnian Muslim civilians by Serb forces to save the lives of a handful of their colleagues captured by Serb paramilitaries; and that the lives of the eight hundred thousand Rwandans slaughtered in that nation's genocide were only worth risking the lives of ten American troops, as declared by an American officer, or not even one more Belgian soldier beyond the ten Belgian troops massacred by Hutu extremists at the beginning of the genocide, as Belgian officials maintained. See Daniela Kroslak, The Role of France in the Rwandan Genocide (London, UK: C Hurst \& Co, 2007); Dallaire, supra note 22 at 522; Laurence de Barros-Duchêne, Srebrenica: Histoire d'un crime international (Paris: L'Harmattan, 1996); Michael Moodie, "The Balkan Tragedy" (1995) 541:1 Annals Am Acad Pol \& Soc Sci 101; Steven L Burg, War or Peace?: Nationalism, Democracy, and American Foreign Policy in Post-Communist Europe (New York: New York University Press, 1996).

26 Wills, supra note 1 at $36,38$. 
comings. Moreover, it underlines the necessity to reform the United Nations' founding laws and procedures, particularly the laws of intervention under chapters 6 and 7 of the UN Charter. At the same time, it emphasizes that the international community must take further steps to end the conspiracy of silence, combat the culture of impunity, and eradicate the UN peacekeepers' human rights violations, including sexual misconduct and exploitation. ${ }^{27}$ This will not be possible without introducing an effective judicial mechanism within the United Nations to bring blue-helmeted perpetrators to justice rather than repatriating them to face prosecution, if any, in their own countries.

27 See Anna Shotton, "A Strategy to Address Sexual Exploitation and Abuse by United Nations Peacekeeping Personnel” 39:1 (2006) Cornell Int'l LJ 97; Elizabeth F Defeis, "U.N. Peacekeepers and Sexual Abuse and Exploitation: An End to Impunity" (2008) 7:2 Wash U Global Stud L Rev 185; Lauren Hunter, "Should We Prosecute the Protectors? Holding Peacekeepers Accountable in Cases of Sexual Exploitation and Abuse" (2009) 1 Carleton Review of International Affairs 15; Muna Ndulo, "The United Nations Responses to the Sexual Abuse and Exploitation of Women and Girls by Peacekeepers During Peacekeeping Missions" (2008) 27:1 Berkeley J Int'l L 127. 